University of Nebraska - Lincoln

DigitalCommons@University of Nebraska - Lincoln

$12-2002$

\title{
Convergent Demographic Effects of Insect Attack on Related Thistles in Coastal vs. Continental Dunes
}

John L. Maron

University of Montana, Missoula

Julie K. Combs

Seattle, Washington

Svata M. Louda

University of Nebraska - Lincoln, slouda1@unl.edu

Follow this and additional works at: https://digitalcommons.unl.edu/bioscifacpub

Part of the Life Sciences Commons

Maron, John L.; Combs, Julie K.; and Louda, Svata M., "Convergent Demographic Effects of Insect Attack on Related Thistles in Coastal vs. Continental Dunes" (2002). Faculty Publications in the Biological Sciences. 60.

https://digitalcommons.unl.edu/bioscifacpub/60

This Article is brought to you for free and open access by the Papers in the Biological Sciences at DigitalCommons@University of Nebraska - Lincoln. It has been accepted for inclusion in Faculty Publications in the Biological Sciences by an authorized administrator of DigitalCommons@University of Nebraska - Lincoln. 


\title{
CONVERGENT DEMOGRAPHIC EFFECTS OF INSECT ATTACK ON RELATED THISTLES IN COASTAL VS. CONTINENTAL DUNES
}

\author{
John L. Maron, ${ }^{1,4}$ Julie K. Combs, ${ }^{2}$ And Svata M. Louda ${ }^{3}$ \\ ${ }^{1}$ Division of Biological Sciences, University of Montana, Missoula, Montana 59812 \\ ${ }^{2} 8840$ Burke Avenue North, Seattle, Washington 98103 \\ ${ }^{3}$ School of Biological Sciences, University of Nebraska, Lincoln, Nebraska 68588
}

\begin{abstract}
Insect herbivory is common, but the conditions under which it reduces the fitness and population size of plants remain poorly understood. We quantified populationlevel impacts of floral herbivory by specialized insects on cobweb thistle (Cirsium occidentale var. occidentale) in a California coastal dune ecosystem, and then compared these demographic effects to those published for Platte thistle (Cirsium canescens) in similarly designed exclusion experiments in the continental sand dune ecosystem in the Great Plains. As a separate test of the strength of the seed-to-seedling linkage, we quantified seedling establishment rates in seed addition plots and compared these results to those obtained in herbivore exclusion experiments. This is the first test of direct vs. indirect methods of evaluating the potential impact of seed loss in plant dynamics. Floral herbivory on cobweb thistle in coastal dunes substantially reduced key components of plant fitness. Reduction of insect feeding within flower heads with insecticide increased mean per capita seed production by $144-316 \%$ and led to a $130-196 \%$ increase in cumulative seedling recruitment in the next generation, depending on dune habitat. Juvenile plant densities around insecticide-treated plants subsequently increased by $>50 \%$. Both seed and flower head addition experiments corroborated the seed limitation of recruitment and juvenile plant establishment for cobweb thistle; exclusion of postdispersal seed predators did not substantially alter this relationship. While seed addition results were qualitatively similar to herbivore exclusion results, seed addition overestimated the seed-seedling transition. These results are broadly parallel to those found previously for Platte thistle in continental dunes, where reduction of insect feeding in Platte thistle flower heads increased mean per capita seed production by $37-240 \%$, depending on year and microhabitat. This reduction in seed translated into a 33-580\% increase in cumulative seedling recruitment and juvenile plant density. Thus in both systems, insect exclusions demonstrated that floral herbivory limited numbers of seeds and seedlings and population density of juvenile plants. This unique comparison of effects of insect herbivory on plant dynamics suggests that for related plants, the character and outcome of such interactions are likely to be functionally similar in structurally convergent ecosystems.
\end{abstract}

Key words: Cirsium canescens; Cirsium occidentale; cobweb thistle; insect herbivory; plant fitness; plant recruitment; Platte thistle; pre-dispersal seed predation.

\section{INTRODUCTION}

Over the past four decades, most research on insectplant interactions has focused on two important conceptual themes. The first theme, motivated by early seminal papers (Fraenkel 1959, Ehrlich and Raven 1964), concerns coevolution and plant defense. This work focused on: the diversity of defenses employed by plants (Berenbaum 1981, Spencer 1988, Rosenthal and Berenbaum 1992), the conditions under which plants produce specific classes of defensive compounds (Feeny 1976, Rhoades and Cates 1976, Bryant et al. 1983, Coley 1983, Coley et al. 1985), and the selective impacts of herbivores on plants (Rausher and Simms 1989, Marquis 1992, Simms and Rausher 1993, Juenger and Bergelson 1998). The second major theme, stim-

Manuscript received 15 October 2001; revised 26 April 2002; final version received 7 May 2002

${ }^{4}$ E-mail: john.maron@mso.umt.edu ulated by the "Green World" paper of Hairston et al. (1960), concerns plants as resources for herbivore populations. This work has focused on: the relative magnitude of bottom-up effects, such as plant vigor, stress, phenology, and resources (Holliday 1977, Witter and Waisanen 1978, Mattson and Haack 1987, White 1984, Price 1991, Watt and McFarlane 1991, Louda and Collinge 1992, Waring and Cobb 1992), and on top-down effects of predators and parasitoids on insect herbivore dynamics (Strong et al. 1984, Tscharntke 1992, Marquis and Whelan 1994, Letourneau and Dyer 1998, Rosenheim 1998, Dyer and Letourneau 1999, Schoener and Spiller 1999, Schmitz et al. 2000).

At the intersection of these topics lie important, yet comparatively unexplored, questions concerning the impacts of herbivores on plant populations. Although a substantial body of work documents the negative effects of herbivores on components of plant performance (reviews: Crawley 1989, 1997, Louda 1989, 
Gange 1990, Marquis 1992), there have been relatively few studies that examine how reductions in performance translate to population-level effects (Hunter 1992). Consequently, we still know relatively little about how and when negative effects of herbivory on individuals are manifest at the population level (but see Louda 1982a, $b, 1983$, Louda and Potvin 1995, Root 1996, Maron 1998, Carson and Root 2000, Fagan and Bishop 2000).

One approach to extending our knowledge in this area, to determine whether there are general patterns in consumer effects on plant populations, is to ask whether demographic effects of herbivores on related plants growing in structurally convergent ecosystems result in qualitatively similar population-level impacts. If this is the case, then similarities among specific case histories may lead to generalizations on the effects of herbivores over a broader set of circumstances. However, because direct comparative studies are rare, controversy continues over the occurrence and frequency of population-level effects of insect herbivores on plant populations.

In this paper, we quantify individual and populationlevel impacts of floral- and seed-feeding herbivores on cobweb thistle (Cirsium occidentale (Nutt.) Jep. var. occidentale) in a coastal dune grassland in California. We then ask whether these impacts are qualitatively similar to those found by Louda and colleagues (Louda et al. 1990 a, $b$, Louda and Potvin 1995) for Platte thistle (Cirsium canescens Nutt.) in the continental dune grasslands in the upper Great Plains (Nebraska). By employing the same experimental methods used by Louda and Potvin (1995), our goal is to evaluate the functional similarity of interactions among related herbivores and plants occurring in geographically separated, but structurally convergent, ecosystems. The experiments include both a direct test of the impacts of predispersal flower head feeders on seed production and seedling abundance, and also an indirect test, achieved through seed and flower head addition, of how reductions in seed input affect recruitment. Although seed addition is the classic assay to determine whether plant populations are seed- or safe-site limited (Harper 1977, Crawley 1992, Turnbull et al. 2000), no previous study has explicitly compared the results from direct tests (exclusion of seed-feeding insect herbivores) and indirect tests (addition of seed).

\section{Methods \\ Natural history of cobweb and Platte thistle and their floral-feeding insect herbivores}

Cobweb and Platte thistles are both monocarpic perennials that inhabit sand dune grassland ecosystems. These thistles germinate in early winter (cobweb thistle) or spring (Platte thistle); neither species has a persistent long-lived seed bank (Louda and Potvin 1995, Palmisano and Fox 1997; J. L. Maron and J. K. Combs, unpublished data). Seedlings of both species grow as basal rosettes that remain in a vegetative state for one to three or more years before they extend a flowering stem (bolt), flower, and die. Cobweb thistle rosettes typically bolt in mid-March and flowering commences by early April. Platte thistle bolts in early May and flowers from mid-May to late June. Both species have determinate flowering and produce large inflorescences on branching stems. Flower heads are produced sequentially, first at the terminal positions on branches from top to bottom and then at subsidiary positions within each branch. Most seeds disperse within 1-2 m around maternal plants (Louda and Potvin 1995).

Both cobweb and Platte thistles are attacked by a suite of specialist thistle-adapted insect herbivores. Flower heads of these thistles are damaged by larvae of two pyralid moths (Pyrausta subsequalis, Homoeosoma impressale), the artichoke plume moth (Platyptilia carduidactyla), and the weevil Baris subsimilis. For cobweb thistle at the Bodega site in California, the most damaging insects were larvae of Homoeosoma impressale (Pyralidae, Lepidoptera). For Platte thistle at Arapaho Prairie in Nebraska, the most severe damage was imposed by two species of tephritid flies, Paracantha culta and Orellia occidentale, which occur early in the season, and by the same moth (H. impressale), which occurs later (S. M. Louda, unpublished data). All of these inflorescence-feeding insects consume flower heads and developing flowers and seeds or damage the receptacle base of flower heads, often causing the florets or flower heads to abort prior to full seed development. Although another insect, the exotic flower head weevil (Rhinocyllus conicus), is now a part of the Platte thistle inflorescence guild in the Great Plains (Louda et al. 1997), the experiments analyzing native insect impact on seed production, population density, and lifetime fitness were done before $R$. conicus invaded (Louda and Potvin 1995).

\section{Study site}

At our site on the University of California's Bodega Marine Reserve (BMR) in Sonoma County, central California, we examined the impacts of herbivores in two distinct habitat types: an "old" dune that is heavily vegetated (especially by grasses) and is a geologically older dune ridge, and a "new" dune that is a more extensive, and in many places more sparsely vegetated, shifting and stabilized dune area that abuts the old dune and lies within the San Andreas Fault. Soil organic matter and nutrient concentrations, as well as vegetative cover, are higher in the old vs. the new dune (Bodega Marine Laboratory, unpublished data; J. L. Maron, unpublished data). The old dune is dominated by introduced annual grasses (principally Bromus diandrus and Vulpia bromoides), bush lupine (Lupinus arboreus), poison oak (Toxicodendron diversilobum), and dune heather (Ericameria ericoides). The new dune consists of stabilized sand and blowouts, and it is dom- 
inated by the introduced dune grass Ammophila arenaria. Cobweb thistle occurs sporadically throughout both of these dunes types, although thistle density is greater along the old dune than in the new dune (J. L. Maron et al., unpublished data).

\section{Experimental protocol}

In early March 1999 in both habitats at Bodega, we randomly selected 100 large cobweb thistle rosettes that were separated from their nearest cobweb thistle neighbor by at least $5 \mathrm{~m}$. We picked from among rosettes that were large enough to bolt since our goal was to examine the influence of flower- and seed-feeding herbivores on seed production and subsequent juvenile recruitment. Each plant was marked with a permanent tag. In each dune type we randomly assigned half of these marked plants to a control and the other half to a herbivore suppression treatment. Half of the plants in each treatment were further subdivided into either a "performance" or "recruitment" group $(N=25$ plants per treatment for both recruitment and performance plants in each habitat). Performance plants were destructively sampled to quantify insect herbivory and seed production. Seed heads were harvested and dissected at the end of the season. Recruitment plants were measured nondestructively, allowing us to quantify subsequent seedling recruitment around insecticidetreated and control plants (as in Louda and Potvin 1995). This necessitated allowing seed heads to mature in situ so that seed dispersal could occur unimpeded. We censused the number of seedlings that emerged within a $1-\mathrm{m}$ radius around each recruitment plant to determine how herbivory on reproductive effort affected subsequent seedling recruitment and plant density. Mature cobweb thistle seed heads often reflex downward or fall completely; a large fraction of the relatively large seeds disperse immediately around parent plants, as is the case for other native thistles (Louda and Potvin 1995; S. M. Louda, unpublished data for Platte, wavyleaf ( $C$. undulatum), and Pitcher's ( $C$. pitcheri) thistles, respectively).

As individuals began bolting, in late March 1999, we sprayed the insecticide ASANA XL (concentration $=0.52 \mathrm{~mL} / \mathrm{L}$; DuPont, Wilmington, Delaware) on half the performance and recruitment plants at 10-15-d intervals, when winds were calm. ASANA is a pyrethroid and is closely related (an isomer) to fenvalorate, an insecticide that has been successfully used in plantherbivore studies (Root 1996, Carson and Root 2000). Control plants were sprayed with water on the same schedule to control for the small amount of water applied to insecticide-treated plants. Starting in January 2000, we regularly censused the number of seedlings that emerged or survived around each recruitment plant. The study had to be terminated in April 2001.

\section{Effects of herbivory on fecundity}

Census procedures.-We censused all performance plants every 2 wk. For each plant, we recorded the number of developing flower heads, flower head position on each branch, and evidence of insect damage. Damage by plume and Pyrausta subequalis moth larvae was diagnosed by evidence of boring into the receptacle base or into the stem subtending flower heads. Internal flower head damage by the moth $H$. impressale was characterized by extensive amounts of sawdust-like frass exuding from between florets within the head. Bimonthly censuses provided an assessment of cumulative flower head production through the season. After flowers were pollinated and seeds began to mature, we enclosed all flower heads with cloth mesh (1.2$\mathrm{mm}$ mesh) to capture seeds prior to dispersal. When seeds had fully ripened, we harvested and stored each head individually in bags that were brought back to the laboratory.

For each harvested seed head, we counted the number of intact viable seeds, scored insect damage, and noted the presence of any insect still within the head. We calculated the mean number of seeds in flower heads at different branch locations on plants (as in Louda and Potvin 1995). We then used location-specific data to estimate seed production for heads at the same positions on "recruitment" plants. To determine if insecticide treatment affected seed biomass, we weighed 20 randomly selected undamaged seeds from a pool of all seeds produced by each insecticide-treated and control plant. Nine plants in the new dune lacked any viable seeds for this analysis.

Analysis.-Initial analyses revealed habitat-related differences in fecundity (see Results: Effects of herbivory on plant fecundity); therefore we analyzed the data collected from each habitat separately. We used MANOVA to test for the effect of herbivore suppression on the potentially correlated traits of number of expanded flower heads per plant and the number of viable seeds produced per seed head. We used $t$ tests with separate variances to determine the effect of herbivory on total per capita seed production and mean seed biomass per plant (MANOVA was not used in this instance because preliminary analysis revealed that these two variables were not correlated). All variables (except seed biomass) were square-root transformed to normalize the variance and meet assumptions of the statistical tests. All statistical tests in this study were performed using SYSTAT 7.0 (SYSTAT 1997).

\section{Seed addition experiments}

Set up.-We performed two seed addition experiments. For the first experiment, we added 60, 120, or 240 mature thistle seeds, collected locally, to randomly assigned $0.5 \times 0.5 \mathrm{~m}$ plots in the new dune. These seed numbers bracket the number of seeds released by a large terminal head that has been either exposed to or protected from insect herbivory. We randomly placed three plots, one for each of the three seed density treatments, within eight large $9 \times 9$ m rodent exclusion or control plots in the new dune $(N=8$ seeds for each 
seed density). Rodent exclusion plots were composed of $1.8 \mathrm{~m}$ tall welded wire $(0.62-\mathrm{cm}$ mesh) dug into the ground $25 \mathrm{~cm}$ and topped with aluminum flashing. Control plots were the same size and height, but were composed of welded wire that was not dug into the ground and that had gates cut along the bottom of the fence to allow entry by rodents. This design allowed us to determine whether postdispersal seed predation by the two major granivores at our site, deer mice (Peromyscus maniculatus) and western harvest mice (Reithrodontomys megalotis), affected the magnitude of thistle seedling recruitment. We added seeds to plots over time to more closely simulate natural seed dispersal phenology and density. We added one-third the total number of seeds ultimately used in each plot in three bouts (on 2, 18, and 25 August 1999), spanning the period when seeds naturally disperse from thistles.

We established a second seed addition experiment involving addition of seed heads to plots, because thistle seeds are dispersed either by falling from seed heads on senesced plants or releasing from fallen flower heads. We added either three insecticide-treated seed heads or three control heads to randomly assigned 0.5 $\times 0.5 \mathrm{~m}$ plots within the large rodent exclusion plots and within the control plots in the new dune. Seed heads were collected from an extra set of plants that were randomly assigned to insecticide or water treatments during July 1999. While on plants, heads were covered with cloth mesh to prevent seed dispersal. On $25 \mathrm{Au}-$ gust 1999, we collected terminal flower heads from identical positions on every plant to ensure that we added similarly sized seed heads to plots. We then added these heads to experimental plots, using a thin wire to anchor each seed head to ensure that they would not blow away from the plots.

Every two weeks from January to July/August 2000 and in early February 2001, we censused the number of newly emerged seedlings in seed and flower head addition plots. We marked each seedling with a colored plastic toothpick and recorded the number of seedlings that had died since the previous census.

Analysis.-We performed a split-plot ANOVA (on log-transformed data) to test the effects of seed number (or seed head type: control or insecticide-treated), rodent exclusion, and the interaction of these factors on the number of thistle seedlings that were alive in early February 2001, $1.5 \mathrm{yr}$ after we had added seeds to plots.

\section{Effects of floral herbivory on seedling recruitment}

Census procedures.-We censused flower head development and damage on recruitment plants every month during the growing season 1999, recording the number and position of each flower head and scoring for insect damage. Then, starting in the first week of January 2000, we recorded thistle seedling density in circular plots $1 \mathrm{~m}$ in radius that were centered on experimental recruitment plants. Since most seeds disperse locally by either dropping from attached heads to nearby sites or remaining in mature heads that ultimately fall directly beside senesced plants (Fenner 1985, Louda and Potvin 1995), it is likely that our plots contained the majority of thistle seeds dispersed off individual plants. Seedlings were censused every 2-4 wk through July 2000, with final censuses performed in February and April, 2001. At each census, we marked newly emerged seedlings with colored plastic toothpicks and recorded how many seedlings that had been previously marked had died between census intervals.

Analysis.-We used $t$ tests with separate variances to examine the effects of herbivory on both the number of inflorescences and total seed production for plants in each habitat. We log-transformed seed production data prior to analysis. We calculated the total number of seeds produced by each recruitment plant by multiplying our field record of the number of flower heads expanded per plant by our laboratory counts (from performance plants) of the average number of viable seeds produced by flower heads at each position within a plant, and summed the total over all expanded flower heads on each plant. We performed linear regression to examine the relationship between total number of viable seeds (square-root transformed) and cumulative seedling recruitment per plant (square-root transformed) in each habitat. To determine the effect of insect herbivore suppression on juvenile plant abundance in the next generation, we used a $t$ test (on square-root transformed data) to compare plant abundance around insecticide vs. control plants at the final census in April 2001.

To compare how well the seed addition experiments estimate the impacts of seed-feeding herbivore suppression on cumulative seedling recruitment, for new dune data we compared the slope of the seed vs. cumulative seedling relationship generated by both seed addition and herbivore suppression. We used a twoway ANOVA on square-root transformed data; response variables were "experiment" (seed addition or herbivore suppression) and seed number. The seed number $\times$ experiment interaction compares the slope of the seed vs. cumulative seedling relationship between methods.

\section{RESULTS}

\section{Effects of herbivory on plant fecundity}

Evidence of insect herbivory was common, and insect feeding greatly reduced cobweb thistle fitness. In the old and new dune respectively, control plants had an average of $64 \%$ and $43 \%$ of their expanded flower heads infested with at least one Homoeosoma impressale moth larva. In the old dune, $76 \%$ of plants had evidence of stem and root boring by moth larvae, often Pyrausta subsequalis; no plants in the new dune had evidence of such moth feeding damage. Insecticide treatment effectively reduced the incidence of attack 
by herbivores. Insecticide-treated plants had an average of $9 \%$ and $11 \%$ of their expanded flower heads infested with $H$. impressale larvae in the old and new dune, respectively.

Experimental reduction of floral herbivory significantly increased key components of thistle reproduction in both the old dune (MANOVA, Wilks' $\lambda=0.49$, $F_{2,47}=23.9, P<0.001$ ) and the new dune (MANOVA, Wilks' $\left.\lambda=0.78, F_{2,45}=6.34, P<0.005\right)$. In the old dune, individual flower heads on insecticide-treated plants produced an average of $90 \pm 5.5$ (mean \pm 1 SEM) viable seeds whereas flower heads on control plants produced an average of $34 \pm 6.2$ viable seeds $\left(F_{1,48}=46.2, P<0.0001\right)$. In the new dune, insecticidetreated flower heads produced an average of $212 \pm$ 40.5 (mean $\pm 1 \mathrm{SEM}$ ) viable seeds compared to $85 \pm$ 28 viable seeds per flower head on control plants $\left(F_{1,46}\right.$ $=12.9, P<0.001)$. The relative effect of floral herbivore attack was similar regardless of the position of terminal flower heads on plants. There was no significant effect of insecticide treatment on mean seed biomass (old dune, $t$ test, $t=0.644, P>0.05$; new dune, $t$ test, $t=-1.27, P>0.05)$.

While cobweb thistles in the old dune produced significantly fewer seeds per head than did new dune plants ( $t$ test, $t=-3.1$, df $=24.6, P<0.006$ ), plants in the old dune area produced a greater number of flower heads that matured than did plants in the new dune ( $t$ test, $t=4.2$, df $=94.1, P<0.0001)$. Insect herbivory had no significant effect on the number of flower heads maturing per plant. In the old dune, insecticide-treated and control plants produced on average a total of 23 and 19.6 flower heads, respectively $\left(F_{1,48}=0.85, P=0.36\right)$. In the new dune, insecticidetreated and control plants produced on average a total of 5.7 and 10.1 flower heads, respectively $\left(F_{1,46}=2.9\right.$, $P<0.095)$.

Overall, insect suppression dramatically increased per capita seed production of cobweb thistle. Insect herbivore reduction resulted in a $144 \%$ increase in viable seed production in the new dune ( $t$ test, $t=2.9$, $\mathrm{df}=42.5, P<0.006)$ and a $316 \%$ increase in seed output in the old dune ( $t$ test, $t=5.4$, df $=38, P<$ $0.0001)$.

\section{Seed addition experiments}

Increasing seed input by seed addition significantly increased seedling establishment over one and a half years (Fig. 1; split-plot ANOVA on log-transformed data from the final census in early February 2001, effect of seed addition $\left.F_{2,47}=9.15, P<0.001\right)$. Rodent exclusion had no effect on seedling number $\left(F_{1,47}=0.04\right.$, $P=0.84)$ nor was there an interaction between seed number and rodent exclusion $\left(F_{2,47}=0.07, P=0.93\right)$. Increasing seed input by adding insecticide-treated seed heads produced a marginally significantly greater number of seedlings over 18 mo than did adding control seed heads (split-plot ANOVA on final census data,

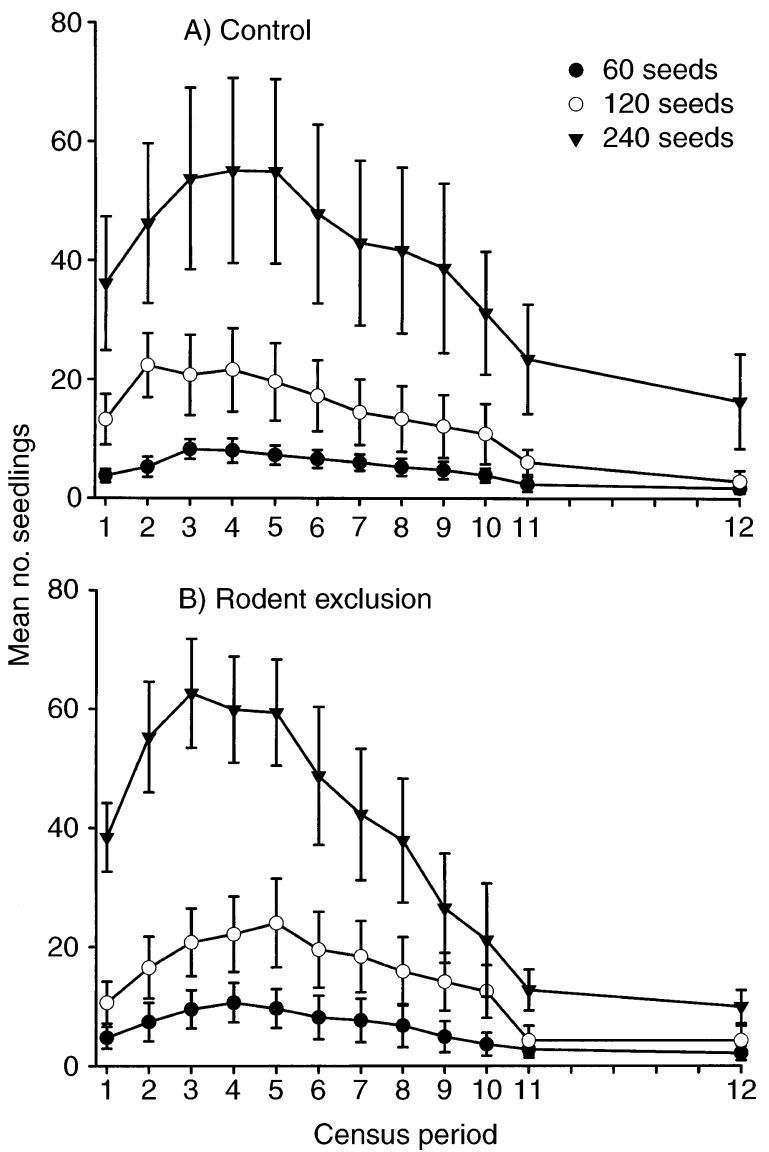

FIG. 1. Effect of seed input on seedling establishment of cobweb thistle in the seed addition experiment: mean no. seedlings ( $\pm 1 \mathrm{SE}$ ) in plots with 60,120 , or 240 thistle seeds added in (A) rodent-open and (B) rodent-protected plots. Census periods (2000-2001): no. $1=5$ Jan 2000, $2=18$ Jan, $3=14 \mathrm{Feb}, 4=3 \mathrm{Mar}, 5=28 \mathrm{Mar}, 6=25 \mathrm{Apr}, 7=11$ May, $8=2$ June, $9=26$ June, $10=27$ July, $11=15$ Aug, and $12=2$ Feb 2001 .

$\left.F_{1,31}=3.85, P<0.071\right)$. There was no overall effect of rodent exclusion on seedling abundance $\left(F_{1,31}=\right.$ $0.04, P=0.84)$; however, there was a marginally significant interaction between seed head type and rodent exclusion (Fig. $2 ; F_{1,28}=3.36, P<0.09$ ). A greater number of seedlings emerged around insect-free vs. control heads in plots protected from rodents compared to plots open to rodents.

\section{Effects of herbivory on seedling recruitment}

For the recruitment plants in the insecticide-treated and control treatments, plants in the old dune produced an average of 16.7 and 13.3 expanded flower heads, respectively ( $t$ test, $t=-0.96$, df $=34.4, P=0.34$ ). An average of $71 \%$ of these expanded flower heads on control plants showed external signs of insect damage vs. $10 \%$ on insecticide-treated plants. In the new dune, insecticide-treated and control plants produced 8.0 and 7.2 expanded flower heads, respectively ( $t$ test, $t=$ 


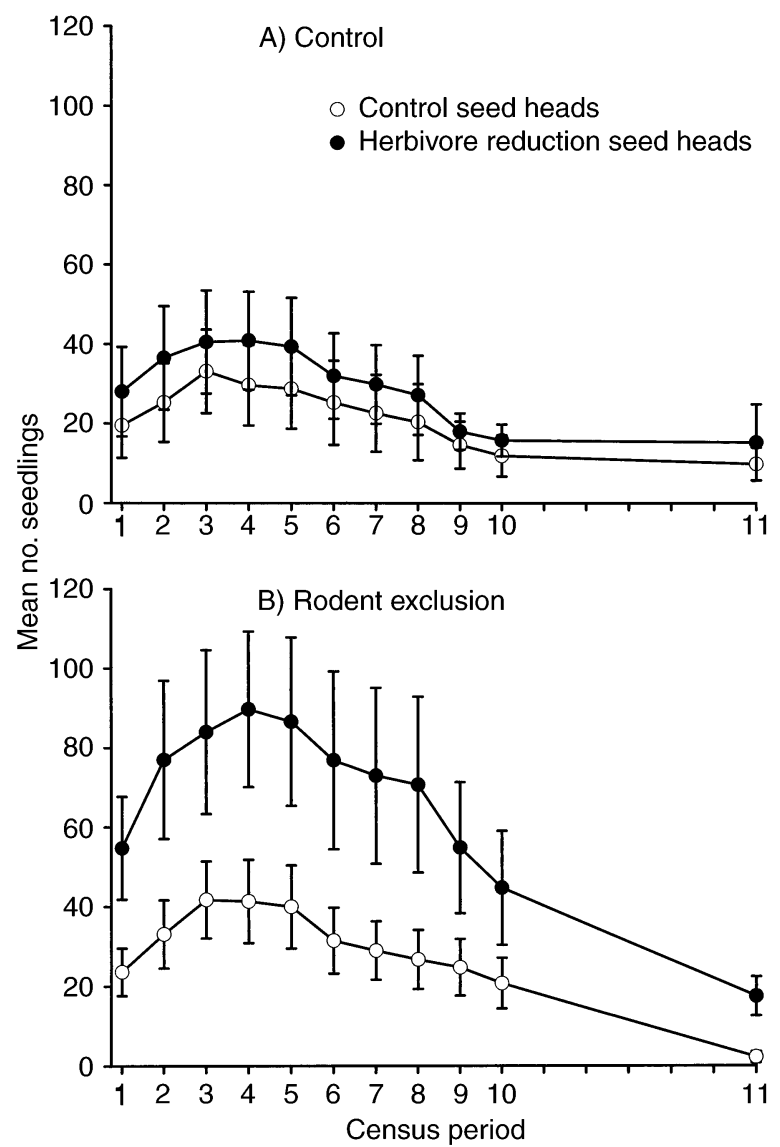

FIG. 2. Effect of seed input on seedling establishment of cobweb thistle in a seed head addition experiment: mean seedlings in plots $( \pm 1 \mathrm{SE})$ with three control or insecticide-treated seed heads added in (A) rodent-open and (B) rodent-protected plots. Census periods as in Fig. 1 except period $11=2 \mathrm{Feb}$ 2001.

0.51 , df $=46.2, P=0.61)$. An average of $57 \%$ of flower heads on control plants had evidence of insect damage, vs. $13 \%$ for insecticide-treated plants.

By combining the inflorescence data above with detailed field measurements and data from dissections of seed heads from the harvested performance plants, we calculated that in the old dune insect herbivore reduction resulted in almost a fourfold higher increase in average number of seed produced per plant (1566 vs. 412 seeds for insecticide-treated and control plants, respectively), a highly significant difference ( $t$ test, $t$ $=9.6$, df $=38.6, P<0.0001)$. In the new dune, herbivore reduction resulted in over a twofold higher increase in mean per capita seed production (842 vs. 375 seeds for insecticide-treated and control plants, respectively), again a highly significant difference ( $t$ test, $t=5.6, \mathrm{df}=43.2, P<0.001)$.

Increased seed production resulting from experimental reduction of insect herbivores directly translated to gains in seedling recruitment by cobweb thistle at Bodega (Fig. 3). Cumulatively, an average of $24 \pm$
5.5 and $10.4 \pm 2.4$ (mean $\pm 1 \mathrm{SE}$ ) seedlings emerged around insecticide-treated vs. control plants in the old dune, respectively, a significant difference ( $t$ test, $t=$ 2.3 , df $=38.9, P=0.03$ ). In the new dune, cumulative seedling recruitment was also much higher around insecticide-treated plants (19.9 \pm 5.2 seedlings), compared to control plants (mean $=6.6 \pm 1.5$ seedlings; $t$ test, $t=2.7$, df $=40, P<0.009$ ). In each habitat, there was a significant positive relationship between estimated seed production and cumulative seedling recruitment $\left(R^{2}=0.27, F_{1,48}=17.6, P<0.0001\right.$ and $R^{2}$ $=0.28, F_{1,45}=17.6, P<0.0001$ for the old and new dune, respectively; Fig. 4).

For the two habitats combined, gains in cumulative seedling recruitment due to herbivore reduction resulted in significantly greater juvenile (12-15 mo old) plant establishment and density ( $t$ test on final census data collected in April 2001: $t=12.24$, df $=82, P=$ $0.028)$. In the heavily vegetated old dune, a $316 \%$ increase in estimated seed production in response to herbivore suppression resulted in a $125 \%$ increase in seed-

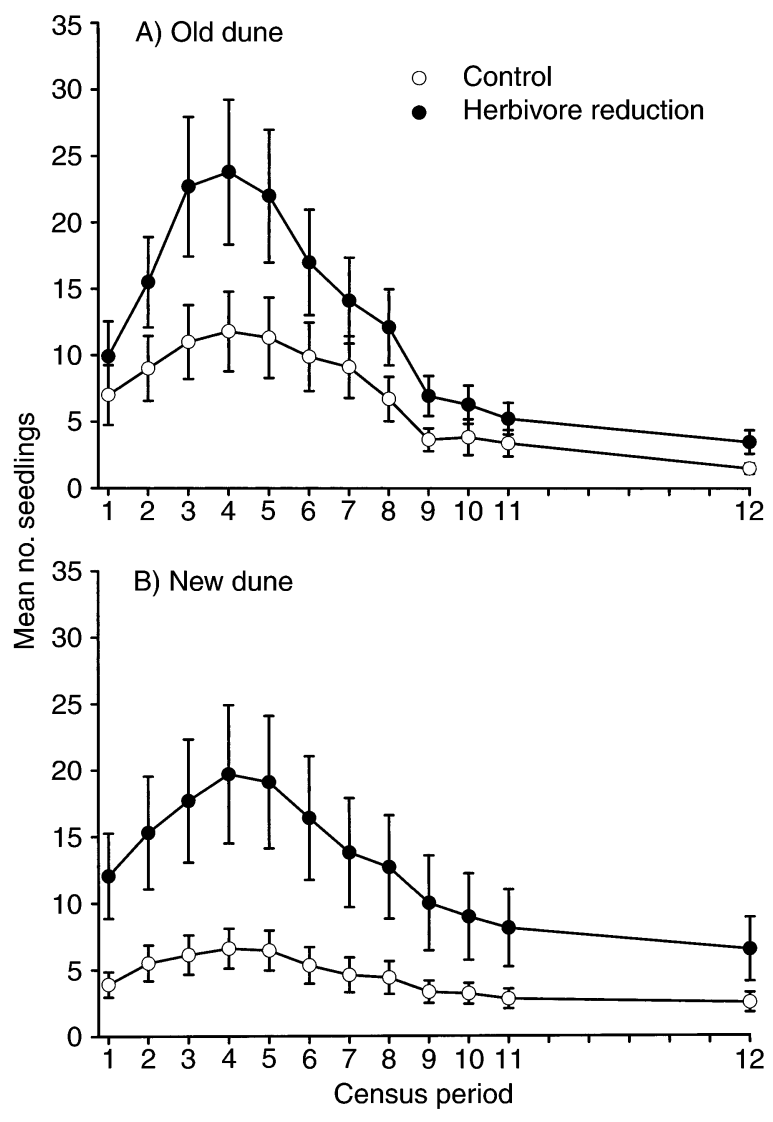

FIG. 3. Effect of herbivore suppression on mean seedling abundance $( \pm 1 \mathrm{SE})$ around control and insecticide-treated cobweb thistle plants in the (A) old and (B) new dune. Census periods (2000-2001): $1=5$ Jan 2000, $2=16 \mathrm{Jan}, 3=14$ Feb, $4=3$ Mar, $5=26$ Mar, $6=25$ Apr, $7=11$ May, $8=$ 2 June, $9=26$ June, $10=27$ July, $11=15$ Aug, $12=2$ Feb 2001, and $13=24$ Apr 2001. 


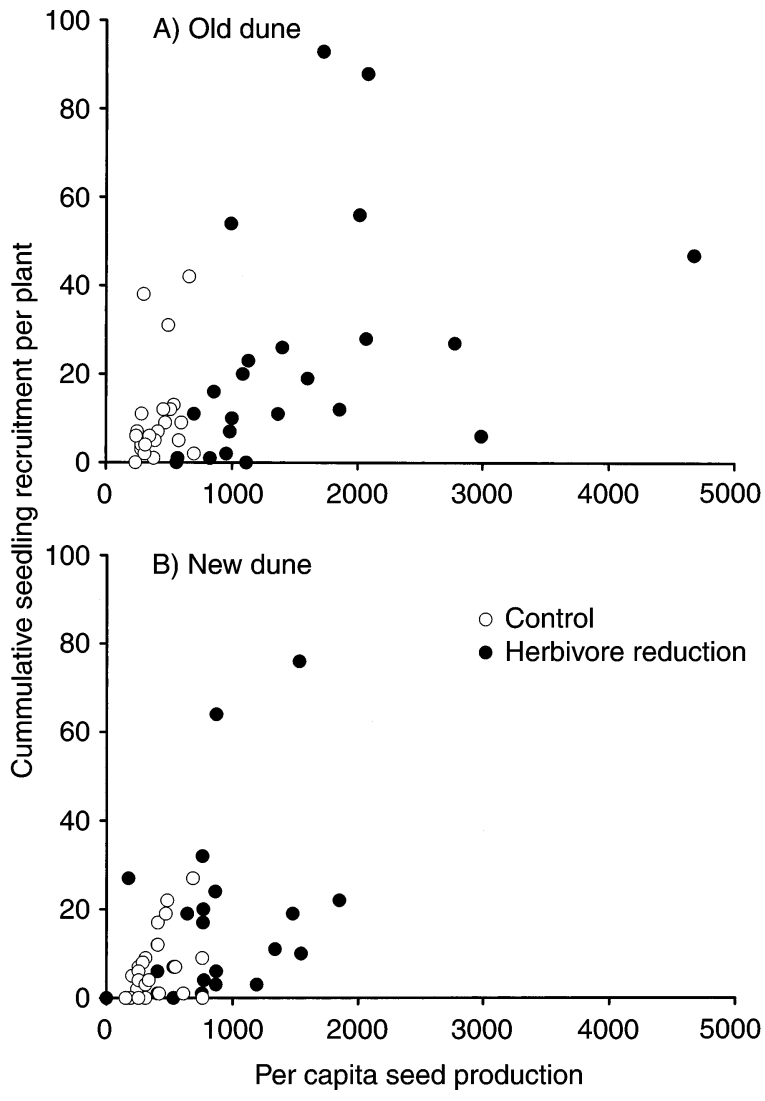

FIG. 4. Positive relationship between per capita seed production and cumulative seedling recruitment (number of seedlings to emerge throughout winter and spring) for control and insecticide-treated cobweb thistle in the (A) old and (B) new dune.

ling establishment and juvenile plant abundance over one and a half years. In the less vegetated new dune, a $144 \%$ increase in estimated seed production in response to experimental reduction in herbivory produced a $107 \%$ increase in seedling establishment. While these effects were not significant for each habitat analyzed separately $(P=0.10$ and 0.12 for old and new dune, respectively), this was likely due to an overall lack of statistical power ( $t$ test power for old and new dune data analyzed separately, with $\alpha=0.05$, was 0.25 and 0.21 , respectively; desired power $=0.8$ ). When the data set was partitioned between habitats, juvenile establishment was quite variable because many control plants with heavy insect damage and little seed production had no juveniles establish around them, and a few insecticide-treated plants had many juveniles establish.

\section{Seed addition vs. herbivore suppression tests of seed limitation}

For both seed addition and herbivore suppression experiments, there was a significant positive relationship between seed number (either seeds we added to plots or seeds produced by plants from which herbivores were excluded) and cumulative seedling recruitment (Fig. $5 ; F_{1,45}=23.2, P<0.001$ ) but no difference between experiments in the mean cumulative numbers of seedling that recruited into experimental plots $\left(F_{1,45}\right.$ $=1.9, P=0.17)$. However, there was a significant experiment $\times$ seed number interaction (Fig. $5 ; F_{1,45}=$ 11.4, $P<0.001$ ), indicating that the slopes of the seed vs. cumulative seedling relationships generated by the two methods in the new dune were different. There were 0.59 seedlings/seed in seed addition plots open to rodents, compared to only 0.10 seedlings/seed around floral- and seed-feeding herbivore exclusion plants in the same habitat. To ensure that this result was not driven by the fact that the range of values for seed number did not fully overlap between the two experiments, we re-analyzed the data after removing all the plants from the herbivore exclusion experiment that produced $>500$ seeds, thereby ensuring that the

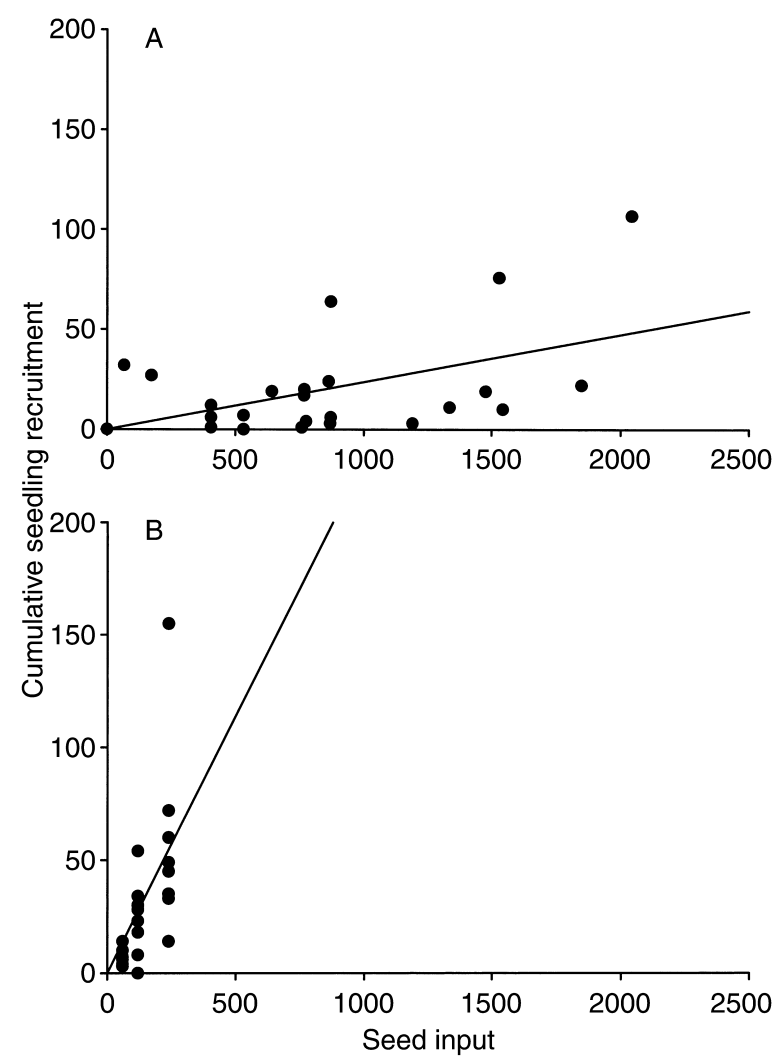

FIG. 5. Comparison of cumulative seedling recruitment vs. seed number for (A) insecticide-treated plants and (B) seed addition plots in the new dune. Seedling recruitment around each insecticide-treated plant was censused in $1 \mathrm{~m}$ radius plots $\left(3.14 \mathrm{~m}^{2}\right)$. In contrast, seed addition plots were $0.25 \mathrm{~m}^{2}$. While the seed addition experiment provides a reasonable estimate of seed limitation (the seed addition vs. seedling recruitment relationship is significant), it overestimates the strength of the seed-seedling transition, thereby underestimating the impact of seed loss on plant recruitment over a more realistic scale. 
TABLE 1. Impact of floral- and seed-feeding insects on seed production and subsequent recruitment of cobweb thistle in coastal California dunes compared with Platte thistle in Nebraska dunes.

\begin{tabular}{|c|c|c|c|c|c|c|c|c|c|c|}
\hline \multirow{4}{*}{$\begin{array}{l}\text { Species and } \\
\text { habitat }\end{array}$} & \multicolumn{5}{|c|}{ Insecticide treatment } & \multicolumn{5}{|c|}{ Control } \\
\hline & \multirow{2}{*}{\multicolumn{2}{|c|}{ No. viable seeds }} & \multicolumn{3}{|c|}{$\begin{array}{l}\text { No. seedlings } \\
\text { established }\end{array}$} & \multirow{2}{*}{\multicolumn{2}{|c|}{$\begin{array}{l}\text { No. viable } \\
\text { seeds }\end{array}$}} & \multicolumn{3}{|c|}{$\begin{array}{l}\text { No. seedlings } \\
\text { established }\end{array}$} \\
\hline & & & \multirow[b]{2}{*}{ Mean } & \multirow[b]{2}{*}{$1 \mathrm{SE}$} & \multirow{2}{*}{$\begin{array}{c}\text { Establishment } \\
\text { probability }\end{array}$} & & & \multirow[b]{2}{*}{ Mean } & \multirow[b]{2}{*}{$1 \mathrm{SE}$} & \multirow{2}{*}{$\begin{array}{c}\text { Establishment } \\
\text { probability }\end{array}$} \\
\hline & Mean & $1 \mathrm{SE}$ & & & & Mean & $1 \mathrm{SE}$ & & & \\
\hline \multicolumn{3}{|c|}{ Platte thistle, continental dunes } & & & & & & & & \\
\hline Blowouts & 96 & 12.4 & 3.2 & 0.92 & 0.033 & 37 & 6.5 & 0.85 & 0.34 & 0.023 \\
\hline \multicolumn{3}{|c|}{ Cobweb thistle, coastal dunes } & & & & & & & & \\
\hline New dune & 877 & 184 & 6.0 & 2.1 & 0.007 & 360 & 110 & 2.2 & 0.70 & 0.006 \\
\hline \multicolumn{3}{|c|}{ Platte thistle, continental dunes } & & & & & & & & \\
\hline Grass & 95 & 19.1 & 1.0 & 0.48 & 0.01 & 61 & 19.8 & 0.2 & 0.11 & 0.003 \\
\hline \multicolumn{3}{|c|}{ Cobweb thistle, coastal dunes } & & & & & & & & \\
\hline Old dune & 1954 & 301 & 3.3 & 0.85 & 0.002 & 470 & 82 & 1.28 & 0.32 & 0.003 \\
\hline
\end{tabular}

Notes: Viable seed production for cobweb thistle is calculated based on head dissections from performance plants. Viable seed production for Platte thistle is the mean of results from experiments initiated in 1984 and 1985 from Louda and Potvin (1995). Seedling establishment is the mean number of progeny per maternal plant that established as one-year-olds (i.e., number of juvenile plants alive in the April or May following treatment for cobweb and Platte thistle, respectively). Platte thistle data are the mean of results of experiments initiated in 1984 and 1985 taken from Louda and Potvin (1995). Establishment probability calculated as the number of progeny that established as one year old plants divided by our estimate of the total viable seeds produced per maternal plant. For cobweb thistles, total viable seed production in this calculation was estimated from recruitment plants. Platte thistle data were taken from combined data (as referred to above) in Louda and Potvin (1995).

ranges of seed numbers generated by the two experiments were more comparable. We again found a significant experiment $\times$ seed number interaction $\left(F_{1,27}=\right.$ 12.0, $P<0.001)$, indicating that the indirect method (seed addition) produced a much steeper slope of seed number vs. cumulative recruitment than did the direct method (herbivore reduction) of estimating herbivore effects. In other words, the percentage reduction in recruitment as seed input declines is greater for seed addition experiments compared to direct tests, indicating that seed addition experiments likely overestimate the seed-to-seedling linkage.

\section{DISCUSSION \\ Impact of insect floral herbivory on plant abundance and fitness}

In California, herbivory on cobweb thistle by flowerand seed-feeding insects was ubiquitous, and it inflicted a substantial amount of damage. The experimental reduction of these herbivores resulted in a 144-316\% increase in seed output, depending on dune habitat. These strong herbivore effects are likely typical for cobweb thistle at our site. Extensive insect herbivory on these plants has been observed in other years (J. L. Maron, personal observations), and a pilot manipulative study using methodology identical to that reported here found that insecticide treatment resulted in a highly significant $12.9 \times$ increase in per capita seed production. Our results are a conservative estimate of the impacts of floral herbivory since an average of 9-11\% (depending on habitat) of expanded flower heads on insecticide-treated plants contained one or more $\mathrm{H}$. impressale larvae.
As for cobweb thistle, flower- and seed-feeding insects commonly attack Platte thistle in continental dunes of Nebraska, reducing plant fitness and density (Louda et al. 1990a, b, Louda and Potvin 1995). Reduction of floral herbivory on Platte thistle growing in the grass matrix (habitat analogous to the old dune at the coastal site) produced a $37-72 \%$ increase in seed production, depending on the year (Table 1; S. M. Louda and M. A. Potvin, unpublished data). In sand blowouts (habitat analogous to the new dune at the coastal site), herbivore suppression resulted in a 112-240\% increase in viable seed production, depending on the year (Table 1; S. M. Louda and M. A. Potvin, unpublished data). Thus, specialist seed-feeding insect herbivores exerted strong effects on the fecundity of two native Cirsium spp. thistles in geographically separated dune ecosystems, although impacts appear even greater for cobweb thistle in the coastal dunes than for Platte thistle in the continental dunes (Table 1).

A fundamental, but largely unanswered, question concerns the extent to which related plants may experience qualitatively similar population-level impacts of herbivory. We have taken one approach to answering this question by using methodology identical to that of Louda and Potvin (1995) to determine whether specialist flower- and seed-feeding insects that attack a coastal thistle have demographic effects similar to those imposed by a similar guild of herbivores that attack a related native thistle growing in continental dunes. For both thistle species, seed loss from herbivory critically reduced the magnitude of both seedling recruitment and juvenile plant abundance. For cobweb thistle, these population effects were evident in three 
ways. First, there was a significant correlation between seed production and cumulative seedling recruitment. Second, adding increasing numbers of seeds to experimental plots resulted in correlated increases in the magnitude of cumulative seedling recruitment. Protecting seeds from rodents only marginally affected this relationship, and only in the case of seed-head addition and not seed addition. Therefore, postdispersal predation on cobweb thistle seeds does not appear to be a significant factor in affecting thistle seed survival. Results from both insect suppression and seed addition experiments provide significant support for the thesis that cobweb thistle populations are strongly seed-limited. Finally, experimental suppression of floral herbivores resulted in an increase in cumulative seedling recruitment and also in juvenile plant establishment. While a limited sample size made it difficult to detect this effect in each habitat in isolation, the combined data from the two habitats revealed a substantial impact of seed herbivory on juvenile plant abundance.

As was true for cobweb thistle, the population effects of floral herbivory on Platte thistle were evident in at least three sets of results (Louda and Potvin 1995). First, increased numbers of seeds associated with experimental reduction of floral herbivory led to increased seedling recruitment in both long-term experiments. This evidence provides significant support for the thesis that Platte thistle populations are strongly seed limited. Second, the suppression of floral herbivores that resulted in an increase in subsequent seedling abundance also led to increased juvenile densities. Finally, increased juvenile densities led to significant increases in the cumulative number of successful flowering (adult) progeny.

Thus, despite the fact that this and the Platte thistle study (Louda and Potvin 1995) were performed across different years in geographically distinct locations with different climates and growing seasons, there is broad qualitative convergence in the overall impacts of insect herbivores on thistle demographics (Table 1). Both Platte and cobweb thistles had qualitatively similar differences in seed-to-seedling transition values between insecticide-treated plants (where seed density was high) and control plants (where seed density was low), indicating that density-dependent seedling mortality was comparable in these two systems (Table 1). While we lack direct evidence on the juvenile-to-adult transition for cobweb thistle, since levels of seedling density dependence were broadly comparable between the two thistle species, it is reasonable to expect that these thistles suffer similar impacts of herbivory on adult abundance. Why might the overall demographic effects of insect herbivory be convergent for Platte and cobweb thistle? Two factors are likely to be important: plant life history and habitat characteristics. Both Platte and cobweb thistles are monocarpic plants that produce relatively large seeds with limited dormancy. Both species, therefore, rely on current seed input for regen- eration and so have little buffering against seed loss. Furthermore, these species occur in moderately open to very open habitats, conditions that favor a closer correspondence between seed input and recruitment (Harper 1977, Fenner 1985). In contrast, more heavily vegetated habitats where plant competition is more intense often render populations microsite rather than seed limited (Crawley 1997).

An additional case in which related species seem to suffer similarly from herbivory involves species of perennial lupines. Both Lupinus arboreus in coastal dunes, and Lupinus lepidus var. lobbii in early successional habitats in Washington, are attacked by a suite of pre- and/or postdispersal seed consumers. Although the consumers that attack these two lupines are not closely related, in both cases heavy herbivory and/or granivory leads to lowered recruitment in the next generation (Fagan and Bishop 2000, Maron and Simms 1997, 2001).

\section{Influence of further trophic interactions?}

Our results, suggesting that insect floral herbivory on cobweb thistle influences plant density at Bodega, differ from those of a previous study. In fact, the contrast likely provides additional insight into the factors influencing demographic outcomes of plant-herbivore interactions. Palmisano and Fox (1997) found relatively low levels of floral herbivory on cobweb thistle associated with very high levels of herbivory by a cottontail rabbit (Sylvilagus bachmani) at Sunset Beach, Santa Cruz, California ( $\sim 220 \mathrm{~km}$ south of our study site). Although the cottontail rabbit $S$. bachmani also occurs at Bodega, densities are low and rabbit herbivory on cobweb thistle at the Bodega site is rare. In addition, although cottontail rabbits (S. auduboni, $S$. floridanus) occur in Nebraska, neither is found in the dry upland habitat of the Sand Hills in the Great Plains (Freeman 1989), where Platte thistle occurs. So, the continental and coastal sites in which insect floral herbivory has been found to be important in thistle density (California coast, midcontinent) are comparable in lacking significant effects by this type of vertebrate herbivore. The implication is that the vertebrate herbivore component of comparative systems can influence the similarities and differences in the effect of insect herbivores on plant dynamics.

One mechanism for the influence of a vertebrate herbivore, such as S. bachmani, on insect herbivore impacts on plants is suggested by additional data we collected to verify the persistence of the interactions reported by Palmisano and Fox (1997). In June 1999, we censused 30 randomly selected flowering cobweb thistles at the Sunset Beach population to compare with data from Bodega. Only 9\% of dissected heads (74 heads total) had evidence of insect damage. In addition, in striking contrast to results from Bodega, we found no evidence of the main insect herbivore, the pyralid moth $H$. impressale, in the flower heads of cobweb 
thistle from Sunset Beach. The densities of cobweb thistle at Sunset Beach are less than half of those at Bodega (J. L. Maron, personal observation). Thus, we postulate that where vertebrate herbivory significantly reduces plant survival and performance, the resulting low plant densities may preclude the presence, persistence, and significant impact by the full guild of insect herbivores expected based on life-history parallels.

\section{Seed addition vs. seed head exclusion of herbivores tests}

Finally, our comparison of seedling recruitment in both insecticide exclusion and seed addition experiments makes two important points. First, the two experimental techniques were broadly similar; both experiments produced a strong relationship between seed number and seedling recruitment, indicating that cobweb thistle populations are seed limited. Second, these tests differed dramatically in their estimation of the magnitude of the effect imposed by predispersal seed destruction on seedling plant densities. In the seed addition experiment, more seedlings were produced per seed than was the case in the herbivore exclusion experiment. Thus, seed addition experiments potentially overestimate the strength of the seed-to-seedling transition (Fig. 5). This suggests that seed addition experiments likely underestimate the impact of seed destruction on plant recruitment.

The difference between tests may be explained in part by the difference in scale between the two types of experiments. Seedling recruitment in seed addition experiments tends to be quantified on a smaller scale (in our case at $0.25-\mathrm{m}^{2}$ area) and involving fewer seeds (in our case from 60-240 seeds) than in herbivore exclusion experiments (which for our experiment was a $3.1-\mathrm{m}^{2}$ area). If there is less heterogeneity in the availability of safe sites on the smaller scale of seed addition plots than around intact plants, such that randomly locating seed addition plots oversamples safe sites, then this could result in differences between tests in estimating seed-seedling transition probabilities. These results highlight the fact that although seed addition experiments can provide valuable evidence for whether plant populations are seed limited, they should not be used as a substitute for direct tests that assess the impacts of herbivores on plant populations.

\section{ACKNOWLEDGMENTS}

We greatly thank: Lora Richards, Abigail McCarthy, Mary Greaves, and Stephanie Theodore for help with field work, Jacoba Charles for assistance in the laboratory, and George Balogh for identification of the moths. Lindsay Amsberry, Ted Evans, Kate Howe, Jon Moore, Jennifer Ruesink, and Amanda Stanley made very helpful comments that greatly improved the paper. As usual, Peter Connors and the staff at the U. C. Bodega Marine Laboratory and Reserve greatly facilitated work in California. Research was supported by NSF grant DEB-9726551 to J. L. Maron and a Research Council of the University of Nebraska grant to S. M. Louda.

\section{Literature Cited}

Berenbaum, M. R. 1981. Patterns of furanocoumarin distribution and insect herbivory in the Umbelliferae: plant chemistry and community structure. Ecology 62:12541266.

Bryant, J. P., F. S. Chapin, and D. R. Klein. 1983. Carbon/ nutrient balance of boreal plants in relation to vertebrate herbivory. Oikos 40:357-368.

Carson, W. P., and R. B. Root. 2000. Herbivory and plant species coexistence: community regulation by an outbreaking phytophagous insect. Ecological Monographs 70:7399.

Coley, P. D. 1983. Intraspecific variation in herbivory in two tropical tree species. Ecology 64:426-433.

Coley, P. D., J. P. Bryant, and F. S. Chapin. 1985. Resource availability and plant antiherbivore defense. Science 230: 895-899.

Crawley, M. J. 1989. Insect herbivores and plant population dynamics. Annual Review of Entomology 34:531-564.

Crawley, M. J. 1992. Seed predators and plant population dynamics. Pages 157-192 in M. Fenner, editor. Seeds, the ecology of regeneration in plant communities. CAB International, Wallingford, UK.

Crawley, M. J. 1997. Plant-herbivore dynamics. Pages 401474 in M. J. Crawley, editor. Plant ecology. Blackwell Science, Oxford, UK.

Dyer, L. A., and D. K. Letourneau. 1999. Trophic cascades in a complex terrestrial community. Proceedings of the National Academy of Sciences USA 96:5072-5076.

Ehrlich, P. R., and P. H. Raven. 1964. Butterflies and plants: a study in coevolution. Evolution 18:586-608.

Fagan, W. F., and J. G. Bishop. 2000. Trophic interactions during primary succession: herbivores slow a plant reinvasion at Mount St. Helens. American Naturalist 155:238251.

Feeny, P. 1976. Plant apparency and chemical defense. Pages 1-40 in J. W. Wallace and R. L. Mansell, editors. Biochemical interactions between plants and insects. Plenum Press, New York, USA.

Fenner, M. 1985. Seed ecology. Chapman and Hall, London, UK.

Fraenkel, G. S. 1959. The raison d'être of secondary plant substances. Science 29:1466-1470.

Freeman, P. 1989. Mammals. Pages 181-188 in A. Bleed and C. Flowerday, editors. An atlas of the Sand Hills. Resource atlas no. 5, conservation and survey division. Institute of Agriculture and Natural Resources, University of Nebraska, Lincoln, Nebraska.

Gange, A. C. 1990. Effects of insect herbivory on herbaceous plants. Pages 49-62 in J. J. Burdon and S. R. Leather, editors. Pests, pathogens and plant communities. Blackwell Scientific, Oxford, UK.

Hairston, N. G., F. E. Smith, and L. B. Slobodkin. 1960. Community structure, population control, and competition. American Naturalist 94:421-425.

Harper, J. L. 1977. The population biology of plants. Academic Press, New York, USA.

Holliday, N. J. 1977. Population ecology of the winter moth (Operophtera brumata) on apple in relation to larval dispersal and time of budburst. Journal of Applied Ecology 14:803-813.

Hunter, M. D. 1992. Interactions within herbivore communities mediated by the host plant: the keystone herbivore concept. Pages 288-325 in M. D. Hunter, T. Ohgushi, and P. W. Price, editors. Effects of resource distribution on animal-plant interactions. Academic Press, New York, New York, USA.

Juenger, T., and J. Bergelson. 1998. Pairwise versus diffuse natural selection and the multiple herbivores of scarlet gilia, Ipomopsis aggregata. Evolution 52:1583-1592. 
Letourneau, D. K., and L. A. Dyer. 1998. Experimental test in lowland tropical forest shows top-down effects through four trophic levels. Ecology 79:1678-1687.

Louda, S. M. 1982a. Distribution ecology: variation in plant recruitment over a gradient in relation to insect seed predation. Ecological Monographs 52:25-41.

Louda, S. M. 1982b. Limitation of the recruitment of the shrub Haplopappus squarrosus (Asteraceae) by flower- and seed-feeding insects. Journal of Ecology 70:43-53.

Louda, S. M. 1983. Seed predation and seedling mortality in the recruitment of a shrub, Haplopappus venetus (Asteraceae), along a climatic gradient. Ecology 64:511-521.

Louda, S. M. 1989. Predation in the dynamics of seed regeneration. Pages 25-51 in M. A. Leck, V. T. Parker, and R. L. Simpson, editors. Ecology of soil seed banks. Academic Press, New York, New York, USA.

Louda, S. M., and S. K. Collinge. 1992. Plant resistance to insect herbivores: a field test of the environmental stress hypothesis. Ecology 73:153-169.

Louda, S. M., K. H. Keeler, and R. Holt. 1990a. Herbivore influences on plant performance and competitive interactions. Pages 414-444 in J. B. Grace and D. Tilman, editors. Perspectives on plant competition. Academic Press, San Diego, California, USA.

Louda, S. M., D. Kendall, J. Connor, and D. Simberloff. 1997. Ecological effects of an insect introduced for the biological control of weeds. Science 277:1099-1090.

Louda, S. M., and M. A. Potvin. 1995. Effect of inflorescence-feeding insects on the demography and lifetime fitness of a native plant. Ecology 76:229-245.

Louda, S. M., M. A. Potvin, and S. K. Collinge. 1990b. Predispersal seed predation, postdispersal seed predation and competition in the recruitment of seedlings of a native thistle in sandhills prairie. American Midland Naturalist 124: $105-113$.

Maron, J. L. 1998. Insect herbivory above- and belowground: individual and joint effects on plant fitness. Ecology 79 1281-1293.

Maron, J. L., and E. L. Simms. 1997. Effects of seed predation on seed bank size and seedling recruitment of bush lupine (Lupinus arboreus). Oecologia 111:76-83.

Maron, J. L., and E. L. Simms. 2001. Rodent limited establishment of bush lupine: field experiments on the cumulative effect of granivory. Journal of Ecology 89:578-588.

Marquis, R. J. 1992. The selective impact of herbivores. Pages 301-325 in R. S. Fritz and E. L. Simms, editors. Plant resistance to herbivores and pathogens. University of Chicago Press, Chicago, Illinois, USA.

Marquis, R. J., and C. J. Whelan. 1994. Insectivorous birds increase growth of white oak through consumption of leafchewing insects. Ecology 75:2007-2014.

Mattson, W. J., and R. A. Haack. 1987. The role of drought in outbreaks of plant-eating insects. BioScience 37:110118.

Palmisano, S., and L. R. Fox. 1997. Effects of mammal and insect herbivory on population dynamics of a native Californian thistle, Cirsium occidentale. Oecologia 111:413421 .
Price, P. W. 1991. The plant vigour hypothesis and herbivore attack. Oikos 62:244-251.

Rausher, M. D., and E. L. Simms. 1989. The evolution of resistance to herbivory in Ipomoea purpurea. I. Attempting to detect selection. Evolution 43:563-572.

Rhoades, D. F., and R. G. Cates. 1976. Toward a general theory of plant anti-herbivore chemistry. Pages 168-213 in J. W. Wallace and R. L. Mansell, editors. Biochemical interaction between plants and insects. Plenum Press, New York, New York, USA.

Root, R. B. 1996. Herbivore pressure on goldenrods (Solidago altissima): its variation and cumulative effects. Ecology 77:1074-1087.

Rosenheim, J. A. 1998. Higher-order predators and the regulation of insect herbivore populations. Annual Review of Entomology 43:421-447.

Rosenthal, G. A., and M. R. Berenbaum, editors. 1992. Herbivores: their interactions with secondary metabolites. Second edition. Volumes I, II. Academic Press, San Diego, California, USA.

Schmitz, O. J., P. A. Hamback, and A. P. Beckerman. 2000. Trophic cascades in terrestrial systems: a review of the effects of carnivore removal on plants. American Naturalist 155:141-153.

Schoener, T. W., and D. A. Spiller. 1999. Indirect effects in an experimentally staged invasion by a major predator. American Naturalist 153:347-358.

Simms, E. L., and M. D. Rausher. 1993. Patterns of selection on phytophage resistance in Ipomoea purpurea. Evolution 47:970-976.

Spencer, K. C. 1988. Chemical mediation of coevolution. Academic Press, San Diego, California, USA.

Strong, D. R., J. H. Lawton, and T. R. E. Southwood. 1984. Insects on plants: community patterns and mechanisms. Blackwell Scientific, Oxford, UK.

SYSTAT. 1997. SYSTAT for Windows: statistics, version 7 edition. SYSTAT, Evanston, Illinois, USA.

Tscharntke, T. 1992. Cascade effects among four trophic levels: bird predation on galls affects density-dependent parasitism. Ecology 73:1689-1698.

Turnbull, L. A., M. J. Crawley, and M. Reese. 2000. Are plant populations seed-limited? A review of seed sowing experiments. Oikos 88:225-238.

Waring, G. L., and N. S. Cobb. 1992. The impact of plant stress on herbivore population dynamics. Pages 167-226 in E. Bernays, editor. Insect-plant interactions. Volume 4. CRC Press, London, UK.

Watt, A. D., and A. M. McFarlane. 1991. Winter moth on Sitka spruce: synchrony of egg hatch and budburst and its effect on larval survival. Ecological Entomology 16:387390.

White, T. C. R. 1984. The abundance of invertebrate herbivores in relation to the availability of nitrogen in stressed food plants. Oecologia 63:90-105.

Witter, J. A., and L. A. Waisanen. 1978. The effect of differential flushing times among trembling aspen clones on tortricid caterpillar populations. Environmental Entomology 7:139-143. 